of his work. However, the chapter on love and sexuality tends to ramble and relies perhaps too heavily on Wittgenstein, Rhees, and literary sources to establish a fairly obvious point that love is a many splendoured thing, and that sexual love involves more than desire. All of this detracts from an otherwise scholarly critique which is developed out of an excellent appraisal of Malinkowski, Klein and Reich.

Whereas Freud and Human Nature concentrates on Freud's views on the role of sexuality in human life, morality, and the relationship between the individual and society, Freud and the Mind is concerned with his account of the unconscious, phantasy, emotions, repression, and free will. Here it is argued that Freud's mechanistic and causal language prevents a full appreciation of his achievements and that his philosophically-based determinism conflicts with his intention to liberate the analysand. Here too Dilman's objective is to remove the 'philosophical froth' from Freud's theory. We find that Freud's determinism is philosophical excess baggage: although he made an original and lasting contribution to psychology 'the language in which he presents his contribution reflects the philosophical prejudices of his time'. Again, it is philosophy that prevents Freud from saying what he wants to say, and it is the philosophy embedded in the popular versions of Freud in the contemporary consciousness that robs his work of any depth. Dilman does not attempt to equip Freudian theory with a more acceptable philosophical framework; his aim is simply to purge the theory from philosophical contamination.

The obvious merit of Freud and the Mind lies in the way Dilman traces the development of Freud's discovery of the unconscious, explores the possible meanings of unconscious memories and phantasies, and examines the extent to which the unconscious can be said to determine thought and action. Nevertheless, it is very hard to assess many of the arguments. Unlike Freud and Human Nature, where Malinkowski's anthropological work is frequently cited, this text suffers from a scarcity of scientific sources. Not a single psychiatric case study is cited. There are no references to recent empirical research, no treatment of recent discussions in the journals of psychiatry. Instead the critique of Freud is conducted with reference to a range of literary characters in the works of Shakespeare, Proust, Dostoyevsky, and Tolstoy. A preference for literary studies over case studies might provide an acceptable mode of philosophical inquiry in some quarters but the value of deriving clinical criteria from literary insights is highly dubious. Psychologists and psycho-analysts would be ill-advised to base their diagnoses on an analysis of Crime and Punishment or recommend a course of therapy on the basis of insights derived from an account of Kitty's selfdeception in Anna Karenina. The attempt to rid Freud of 'philosophical froth' ultimately involves the replacement of Freud's philosophical presuppositions with those held by fiction writers. Dilman has attempted a bold and original critique of the philosophical underpinnings of psychoanalysis, but his almost exclusive reliance upon fiction and an unquestioned appeal to the authority of Wittgenstein, Weil, Rhees, suggests that the book is of greater value to the literary critic than the clinical therapist.

DAVID LAMB Lecturer in Philosophy, University of Manchester

\section{The Influence of Christians in Medicine}

Editors, J T Aitken, H W C Fuller and D Johnson, 186 pages, London, $£ 3.95$, Christian Medical Fellowship, 157 Waterloo Rd, SE1 8XN, 1984

Thirteen of the chapters in this book appear to have been written cooperatively by the editors, and one, on 'The Spread of Western Medicine', is by Gordon A D Lavy. The book is designed primarily for Christian medical folk of an evangelical outlook, in the sense that after the Reformation period it concentrates on 'Protestant medical circles. But it is in no sense a partisan work. It is written in an eirenic spirit, and makes full allowance, among other matters, for the contribution of Arabs and Jews in the development of medicine. Since we tend to be preoccupied with the issues and controversies of our own time it is wise to achieve a sense of perspective by reflecting on how we came to where we are, and this is true of Christians and the Christian tradition in medicine.

This book is narrative rather than analytical history, fitting the contribution of outstanding individuals into an historical framework. Henceforth, it is remarked, this will no longer be possible because increased technical complexities have made medicine much more a corporate activity. How a Christian contribution can best be made in these circumstances is beyond the scope of the book. There are hints of a polarisation between Christianity and what is incidentally referred to as 'agnostic', 'atheist' or 'scientific' humanism which could make such a contribution difficult. If the hints were developed they would probably over-simplify the polarity. But parallel to this is the contention that monotheism is a stimulus to medicine because it means we view the world as orderly, and not as subject to the caprice of pagan deities or mere chance. The picture emerges of a long line of devoted individual practitioners, often embroiled with a Church frequently in error, sometimes corrupt, and inclined to be jealous. The defects of the individuals concerned are by comparison underplayed. Physicians and surgeons naturally are the focus of attention, but in modern times representatives of nursing and preventative medicine are brought into the narrative. There are no specific references, but details of the chief sources consulted and an index of all the persons referred to, as well as a subject index, are provided. The book deliberately excludes psychological medicine, as being too large a field, and 'faith healing' because its concern is with 'orthodox medicine'. If there are any remnants of the idea around that Christianity has been hostile to the latter down the centuries (an idea propagated by secularist movements earlier in this century), this book will scotch them. Of modest size, this book may well be of interest to others beyond the Christian Medical Fellowship for whom it was produced.

RONALD PRESTON Emeritus Professor of Social and Pastoral Theology, Manchester University

\section{Professionalism and the Empowerment of Nursing}

American Nurses' Association, 76 pages, Missouri, American Nurses Association, 1982.

This is a collection of papers concerned with the professional status of nursing and, more importantly, with the power which goes along with that status. The papers were presented at the 53rd convention of the American Nurses' Association in 1982. According to the preface the papers in this volume 'show the determination of nurses to take the 
power they deserve as professionals and to exercise it individually, collectively and in concert with other professionals to promote better and more costeffective health care for all persons, especially those who have least access to it'.

The position taken in these papers is that if nurses are to act in a professional way they must have the power to enable them to do so. The nurse's role is said to be that of patient advocate within the complex organisational settings of health care. Nurses have responsibilities to patients, to the organisation and, if professional status is to be achieved and sustained, to their professional association. In trying to respond to these responsibilities, the nurse encounters ethical issues and may be faced with moral dilemmas.

Thompson's paper, Conflicting Loyalties of Nurses Working in Bureaucratic Settings, addresses these ethical issues. The paper centres on the case of a mother who asks to hold her baby (after a normal delivery) and is met with some unwillingness on the part of the nurse, who wants to weigh the baby and place it in the 'warmer'. The questions Thompson raises from this everyday type of situation are 'How is it that child-bearing women have to ask if it is all right to hold their own baby?'; 'What has happened to hospitaloriented childbirth that it is forcing some couples to choose out-of-hospital care, or no care at all rather than submit their bodies and normal life experiences to the control of others - doctors, midwives and nurses?'; 'Who makes hospital policies and for whose benefit are these policies made?'
Thompson's main argument is that nurses should examine their daily practice, looking especially at the ethical aspects of their decisionmaking. If nurses are to 'live up to their status as professionals they must,' she argues, 'practise in an ethical manner, and this means studying ethics in order to determine what is ethical practice'. It has to be said that, as with some of the other papers in this collection, the questions make rather more interesting reading than the attempts to address them. One does not expect the impossible to be achieved in that answers are produced to ethical dilemmas, but a little more imaginative discussion would have been welcome. Exceptions to this disappointing trait are to be found in the papers by Margretta Styles and Richard Hall.

In all it is a useful collection, with the emphasis laid more upon professionalism and power than ethical debate.

KATH M MELIA

Lecturer, Department of Nursing Studies Faculty of Social Sciences University of Edinburgh

\section{Health, Disease, and Causal Explanations in Medicine}

Editors, Lennart Nordenfelt, B Ingermar and B Lindahl, 256 pages, Dordrecht/Boston/Lancaster, D Reidel, 1984.

Medical ethics is a subject which by now is familiar and acceptable to most doctors, but, because of its strongly normative aspects is not acceptable to all philosophers as a part of philosophy The reverse may be true of the philosophy of medicine, a disciplinê? which because of its highly theoretical and conceptual nature is nearer to the main stream of philosophy and further from the practical concerns of doctors This book offers essays of philosophical nature on the concepts of health and disease, and the various ways in which the concept of causality is involved in our understanding of these $\overrightarrow{0}$ concepts. Several of the essays deal withthe analysis of different models of $\vec{\omega}$ health and disease. For example, biological, descriptive views are contrasted with evaluative views and the question considered what is the $\overrightarrow{-}$ primary subject of health - the wholeiv person or the parts of the body. There is discussion of definition and classification in medicine and of causality in general as well as in medicine. Apart from discussions of $\mathrm{a}^{-}$ philosophically familiar kind on causality there is an interesting section on causal assumptions in holisticmedicine. This is a worthwhile book which makes a real contribution to fir understanding of various conceptra problems in medicine, but it is not for the philosophical beginner. authors are a mixture of scientists physicians, social scientists anch philosophers and the book is the outcome of a symposium in Stockholm $\overrightarrow{\vec{b}}$ - the first Nordic Symposium on the Philosophy of Medicine. R S DOWNIE
Philosophy Glasgow University 